\title{
Work Out \\ Numeracy
}

Ted Penketh

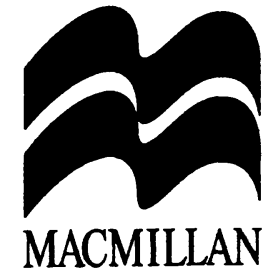


C F. E. Penketh 1987, 1996

All rights reserved. No reproduction, copy or transmission of this publication may be made without written permission.

No paragraph of this publication may be reproduced, copied or transmitted save with written permission or in accordance with the provisions of the Copyright, Designs and Patents Act 1988, or under the terms of any licence permitting limited copying issued by the Copyright Licensing Agency, 90 Tottenham Court Road, London W1P 9HE.

Any person who does any unauthorised act in relation to this publication may be liable to criminal prosecution and civil claims for damages.

First edition 1987

Reprinted four times

Second edition 1996

Published by

MACMILLAN PRESS LTD

Houndmills, Basingstoke, Hampshire RG21 6XS

and London

Companies and representatives

throughout the world

ISBN 978-0-333-66270-0

ISBN 978-1-349-14099-2 (eBook)

DOI 10.1007/978-1-349-14099-2

A catalogue record for this book is available from the British Library.

109

12111009080706 


\section{Contents}

How to use this book vi

Acknowledgements vii

1 Number 1

1 How big is a number?

2 Addition 2

3 Addition from information given 4

4 Subtraction 7

5 Multiplication 9

6 Division $\quad 12$

7 Priorities $\quad 15$

8 Multiplication of whole numbers by 10, 100, 1000 etc. 16

9 Multiplication of numbers ending in $0 \quad 16$

10 Division of whole numbers ending in 0 by 10, 100, 1000 etc. 16

11 Division of two whole numbers ending in $0 \quad 17$

12 Approximations 17

13 Directed numbers $\quad 19$

14 Rules for directed numbers $\quad 19$

15 Number sequences $\quad 21$

2 Fractions 23

1 Introduction 23

2 Changing fractions to equivalent fractions 24

3 Cancelling fractions $\quad 25$

4 Comparison of fractions 26

5 Improper fractions and mixed fractions $\quad 27$

6 Addition and subtraction $\quad 29$

7 Multiplication $\quad 30$

8 Division 31

9 Priorities $\quad 32$

3 Decimals $\quad 36$

1 Place value $\quad 36$

2 Converting simple fractions to decimals and decimals 37

3 Addition and subtraction $\quad 38$

4 Multiplication $\quad 40$

5 Multiplication and division by powers of 10

6 Division $\quad 42$

7 Corrected decimals $\quad 43$

8 Significant figures $\quad 44$

9 Corrected significant figures $\quad 45$

10 Changing any fraction to a decimal 46

11 Standard form 46

4 Money 49

1 Money and decimals $\quad 49$ 
5 Introducing the calculator

1 Introduction $\quad 55$

2 Use of a calculator $\quad 55$

3 Addition $\quad 56$

4 Subtraction $\quad 57$

5 Addition and subtraction $\quad 57$

6 Multiplication $\quad 58$

7 Division $\quad 59$

8 Mixed operations $\quad 60$

6 Measurement 62

1 Imperial and metric measures $\quad 62$

2 Changing units 63

3 Changing imperial units to metric units 64

4 Time $\quad 67$

7 Ratio and proportion $\quad 70$

1 Ratio as a comparison $\quad 70$

2 Proportional parts $\quad 72$

3 Scales and maps $\quad 74$

4 Direct proportion $\quad 77$

5 Inverse proportion $\quad 78$

8 Averages $\quad 81$

1 Arithmetic mean $\quad 81$

2 Median $\quad 84$

9 Speed, distance and time $\quad 87$

1 Average speed $\quad 87$

10 Commercial arithmetic $\quad 91$

1 Introduction 91

2 Payslips and wages 91

3 Bank paying-in slips 93

4 Postal charges $\quad 95$

5 Foreign currency and exchange rates 98

6 Credit agreements 102

7 Bank loans 105

8 Insurance 106

9 Budgeting 109

11 Percentages 111

1 Introduction $\quad 111$

2 Percentage as a fraction $\quad 111$

3 Percentage as a decimal $\quad 112$

4 Changing any fraction or decimal to a percentage 113

5 One number as a percentage of another $\quad 114$

6 Percentages in money 116

7 Percentages of other quantities 118

8 Percentage increase or decrease $\quad 119$

9 Value added tax $\quad 120$

10 Gas and electricity bills $\quad 121$

11 Profit and loss $\quad 124$

12 Interest 129

13 Simple interest 129

14 Compound interest 130

15 Income tax 132

16 Building societies 135

17 Percentages with the calculator 135 
12 Graphs, substitution, coordinates and surveys

1 Graphs

2 Line graphs

3 Bar graphs (bar charts)

4 Proportionate bar graphs

5 Pie charts

6 Pictograms

7 Straight-line graphs

8 Curved graphs

9 Substitution

10 Further substitution

11 Formulae and equations

163

12 Coordinates, maps and grid references

13 Simple algebraic graphs

14 Data and graphs

172

15 Questionnaires, surveys and results

16 Surveys by questioning or questionnaire

17 Flowcharts

13 Plane shapes

1 Common shapes

2 Straight lines and angles

3 Bearings

4 Rectangles and squares

5 Perimeters

189

6 Area of rectangles

7 Costing

8 Triangles

9 Perimeter of triangles $\quad 197$

10 Area of triangles 197

11 Circles

12 Circumference of circles 199

13 Area of circles 202

14 More use of the calculator 207

1 Use of memory 207

2 Using a constant $\quad 209$

3 Square root $\quad 211$

15 Space shapes $\quad 213$

1 Volume $\quad 213$

2 Measurement of volume $\quad 213$

3 Volumes of right prisms $\quad 213$

4 Surface area $\quad 219$

5 Importance of surface area 219

16 Assignments $\quad 225$

1 Introduction $\quad 225$

2 Equality or not $\quad 225$

3 Business studies students' Christmas party 226

4 Careful driving $\quad 226$

5 Timetables $\quad 227$

6 The newsagent $\quad 232$

7 The student $\quad 233$

8 Smoker and non-smoker 233

9 Decorating 234

10 The garden $\quad 235$

11 The holiday venture $\quad 237$

Answers to exercises $\quad 239$

Index $\quad 259$ 


\section{How to Use this Book}

The aim of this book is to provide a working knowledge of basic mathematics and, at the same time, to concentrate on essential topics that occur in first-level examinations.

The book has sufficient material to cover the syllabus for NCVQ Core Skills Levels 1 and 2, Application of Number, and City and Guilds and GCSE Numeracy examinations; also, GCSE candidates who are looking for a medium grade will find plenty of help in this book.

The methods used for each chapter are similar: a brief revision or statement of facts for the heading given; a large number of worked examples to cover all levels of the examinations mentioned; and numerous exercises and multiple choice questions to meet the ever-increasing demand for those asking for more practice. Where any question proves difficult it can be answered by careful reference to the worked examples.

To keep pace with everyday life the sections on percentages and graphs have been increased considerably. Many worked examples reflect up-to-date changes and conditions, while all exercises and multiple choice questions are new.

Significant changes have been made in this second edition, with much additional material to satisfy the changing demands of first examinations. Opportunity has been taken also to bring the use of the calculator into operation after appropriate chapters, and guidance is given where this is applicable. I am very grateful to those who have written making suggestions along these lines.

Mathematics is an enjoyable subject, not something of which to be frightened, and it is hoped that this book will go some way to being a springboard for higher things.

Ted Penketh

September 1995 


\section{Acknowledgements}

The author and publishers wish to thank the following, who have been of assistance in the compilation of this book or who have kindly given permission for the use of copyright material to illustrate particular points: British Airways, British Rail, Casio Electronics Co. Ltd, the Department of Transport, the Electoral Reform Society, The Guardian, HM Statistical Office, The Independent, ParcelForce, The Post Office, Ribble Bus Company.

Every effort has been made to trace all the copyright holders, but if any have been overlooked the publishers will be pleased to make the necessary arrangements at the first opportunity. 